УДК 82-1.09:159.922.1

Колядка С. В. кандидат філологічних наук, доиент Інститут мови і літератури імені Якуба Коласа і Янки Купали НАН Республіки Білорусь

\title{
МАСТАЦКАЯ «ІДЭНТЫЧНАСЦЬ» ПАЭТЫЧНАГА ТВОРА Ў «ЖАНОЧЫМ» І «МУЖЧЫНСКІМ» ПІСЬМЕ
}

У статті розглядаються способи організаиії поетичного тексту на лексико-семантичному рівні, який постав як його «формальна ідентичність». Автор аналізує особливості чоловічого й жіночого стилів, які утворюють моделі чоловічого й жіночого письма. У якості об'єкта і предмета вивчення виступає сучасна поезія.

Ключові слова: чоловіче та жіноче письмо, ідентичність.

В статье рассматриваются способы организации поэтического текста на лексико-семантическом уровне, который предстает его «формальной идентичностью». Автор анализирует особенности мужского и женского стиля, которые и образуют модели мужского и женского письма. В качестве объекта и предмета изучения выступает современная поэзия.

Ключевые слова: женское, мужское письмо, идентичность.

In the article the ways of organization of poetic text are considered at lexicosemantic level which appears as it "formal identity». The author analyzes features of male and female style which form models of the male and female writing. The modern poetry acts as an object and a subject of studying.

Key words: male and female writing, identity. 
«Я кахала», «я кахаў» - толькі формы прошлага часу дапамагаюць нам вызначыць, што ў першым выказванні прызнанне выказана жанчынай, а ў другім - мужчынам. Але калі гэты выраз ужывем у цяперашнім часе - «я кахаю» - то ён пачынае губляць полавую прыналежнасць. Дадзены лінгвістычны аспект ужывання дзеяслова «кахаць» ў розных формах часу ўспрымаецца шаблонным прыёмам размеркавання роляў у мастацкім тэксце, аднак, як мы ўжо заўважылі, і ён не з'яўляецца ўніверсальным. Тое ж можна сказаць і пра вобразнае выяўленне ў паэзіі. Сучасныя аўтары часта пазбягаюць першай асобы ў паэтычнай размове, умела абыходзячы выкарыстанне асабовых займеннікаў і звяртаючыся да іншых форм, напрыклад:

Яна новы дзень падвойным пачне эспрэса:

усё як звычайна, ведаеш, без экстрыму.

Усё як звычайна: сиіснуцьь душу пад прэсам, пачуиці схаващь пад слоем таўшчэзным грылу

ды - «асталавіста» - гэта яе ауттобус,

там людзі з пустымі сэрияамі і вачьлма... [Гронская 2011: 76]

«Яна» - займеннік трэцяй асобы жаночага роду, наяўнасць гэтага займенніка ў паэтычным тэксце не пакідае сумненняў у тым, аб кім ідзе размова, аднак сумненні заўсёды будуць заставацца адносна таго, хто напісаў гэтыя радкі - жанчына ці мужчына, асабліва ў тым выпадку, калі пад імі не падпісан аўтар. Нявытраманая рыфма і рознаскладовая разбіўка радкоў не падказвае нам аўтарскую прыналежнасць - гэта ў цэлым «безасабовы» спосаб афармлення тэксту, ідэйная скіраванасць твора таксама не мае полавага прымацавання - пра душэўны стан «Яе» мог напісаць і мужчына. Такім чынам, у любым паэтычным творы знойдуцца фармальныя і нефармальныя паказчыкі аўтарскай асобы. У дадзеным урыўку позірк чытача спыніцца на радку «пачуцці схаваць пад слоем таўшчэзным грыму», які, сыходзячы з пункту гледжання 
псіхолагаў, наўрад ці можа належыць мужчыне (нават улічваючы нашу сучаснасць 3 прысутнасцю ў ёй гееў, бісексуалаў і г. д), «пачуцці пад грымам» - гэта ўвасабленне траўміраванай жаночай свядомасці і жаночага самаўсведамлення, што карыстаецца атрыбутамі жаночага...

Верш Вольгі Гронскай «***Яна вечарамі крыжыкам вышывае...» перадае перажыванні маладой дзяўчыны, якая нібы з боку пазірае на ўласнае існаванне, а таму і з'яўляецца займеннік яна. У другім вершы «***Ты зноў ідзеш пра сны і міражы» гэта ж паэтка ўжывае займеннік $m b l$, які зноў жа не мае полавай «акрэсленасці». На працягу ўсяго тэкста мы не знойдзем ні адной часціны мовы, якая б указвала на жаночы род. «Унісекс» кіруе не толькі сучаснымі тэндэнцыямі ў модзе, але і ў літаратуры. Маладыя аўтары часта не засяроджваюцца на выяўленні прыроднага пачатку, сваёй жаночай/мужчынскай існасці праз мастацкае слова - гэта мэта становіцца другараднай ці ўвогуле неістотнай у творчым самараскрыцці. Аднойчы я пачула развагі адной 3 аўтарак, маладой дзяўчыны (спрабуе сябе ў празаічным жанры), якая заявіла, што ніколі не задумвалася аб тым, якая яна ўнутры - мужчына ці жанчына і ад якога імя яна наогул выкладае думкі ў мастацкім творы. «Унісекс» - гэта самае дакладнае вызначэнне народжанага ў бясполым кругазвароце думак твора. Прычым вобразы тэкста губляюць не толькі прыродныя атрыбуты жаночага, але і сацыяльныя і культурныя канструкты асобы.

На мой погляд, пазіцыянаванне сябе як бясполай істоты не надае дзяўчыне-празаіку дадатковага арэолу таямнічасці і гэтым не прыцягвае большай увагі да яе тэкстаў. Мне, як чытачу, хочацца ўбачыць не новую версію аўтарскага «я» (пры гэтым я абсалютна не супраць гэтага), а за вобразам любога літаратурнага твора асобу - адмоўную ці станоўчую - але доказную, абгрунтаваную ў сваіх паводзінах і настроях i, галоўнае, зразумелую мне ў сваіх памкненнях, жыццёвых тактыках і стратэгіях, нават калі яны не адпавядаюць агульнапрынятым нормам. Аднак як гэта здзейсніць аўтару, 
калі гэты аўтар яшчэ не вызначыўся ў полавай прыналежнасці. Аўтарскае «я» павінна несці на сабе асноўную нагрузку ў спосабе падачы думкі, эмоцыі, перажывання ў творы. Аднак «бясполы» аўтар трапляе ў пастку ўласных эксперыментаў, што ў выніку можа прывесці да крызісу ідэнтычнасці. Як адзначыў В. Хёсле, «фармальная ідэнтычнасцьь з'яўляещияа якасию кожнага аб'екта... рэальная ідэнтычнасць прыналежна толькі эмпірычным аб'ектам $i$ мае розныл формы у залежнасці ад анталагічнага статуса дадзенага канкрэтнага аб'екта» [Хёсле 1994: 112].

Як гэтыя развагі філосафа працуюць у літаратурным творы? Калі верш напісаны адпаведна з патрабаваннямі да гэтага жанра гэта фармальная ідэнтычнасць: ён мае рыфму, пэўную рытміку, славесную арганізацыю, насычаны пэўнымі мастацкімі стылявымі прыёмамі і г. д. Аднак не кожны твор, напісаны ў адпаведнасці 3 правіламі стварэння паэтычнага арганізма, набудзе доўгае літаратурнае жыццё. Вось тут варта гаварыць пра індывідуальную (рэальную) ідэнтычнасць верша, як пра захаванне яго формы i зместа ў часе, як пераадоленне ўціску на яго іншых форм, напружанай барацьбы паміж падобнымі формамі ў іншых аўтараў і г.д (напрыклад, санетаў, створаных у беларускай літаратуры шмат, аднак «выжываюць» і застаюцца непераўзыйдзенымі шэдэўрамі сярод санетаў толькі асобныя, адзінкавыя, якія і становяцца ў выніку літаратурным канонам).

«Рэальная ідэнтычнасць» верша - гэта яго душа, яго стрыжань, яго энергетыка, якая захоўваецца і праз стагоддзі і ўздзейнічае на чытача па-за прасторай і часам. Часта верш, цікавы для самаго аўтара, бо выкліканы пэўнымі падзеямі ці ўражаннямі ў яго жыцці, з'яўляецца нецікавым для іншых чытачоў, хаця фармальна вытрыманы ўсе параметры формы. Форма - гэта базіс ментальнай сутнасці твора, а ўлічваючы тое, што ў сучаснай паэзіі форме надаецца вялікая ўвага, то і форма пачынае выконаваць ролю самадастатковай інстанцыі .... Звернемся да верша Аксаны Спрынчан, актыўнага эксперыментатара 3 формай: 
***

ТУТ

злева направа

і справа налева

ТУТ

ТУТ

упершыню

і ўглыбіню

ТУТ

ТУТ

выюць па мне ваўкі

доўгім працяглым «У»

ТУТ

ТУТ

дзве літары «Т»

крыжам стануць маім

ТУТ

ТУТ

створаць

бясконцасць

ТУТ

Паэтэса шукае адпаведнасці формы тэкста форме слова i наадварот. Спрынчан стварае не толькі стройную, прыгожую звонку канструкцыю верша, але і імкнецца пажангліраваць словам: углядваецца ў будову лексемы «тут», вышуквае арфаэпічныя тонкасці вымаўлення слова, будуе з літар крыжы і г. д. Аднак за гэтай працай са словам больш гульні, чым сэнсу. Спрынчан прадэманстравала філалагічную адукаванасць, лінгвістычную зоркасць, інтуітыўную праніклівасць, аднак не ўразіла, не кранула душу, не зачапіла думку. Усё яе эксперыменты вычарпаны ў межах інтэлектуальнага раскладання формы і зместу слова «тут», прастора верша абмежавана дадзенымі інтэлектуальнымі выкру- 
тасамі, няма выхаду ў іншую прастору - прастору здагадак, эмацыянальнага перажывання і г. д. Зразумела, не кожны верш абавязаны хваляваць і ўзрушваць пачуцці, аднак роля верша не павінна зводзіцца да трэніроўкі думкі, праверкі логікі і ведаў, для гэтага існуюць іншыя дысцыпліны. Кожны слупок самастойны i завершаны, паэтэса нібы імкнецца здзівіць чытача: паглядзі, а ў слове ёсць яшчэ адно прачытанне. Перад намі - вынік думкі аўтара без канатацый, якія ў выніку і ствараюць гісторыю верша, надаючы яму «цікавасць» і рэальную (індывідуальную) ідэнтычнасць. «ТУТ» - гэта момант быцця, які асэнсоўваецца праз плынь свядомасці: усё, што трапляе ў дадзены момант у кругазварот думак, выносіцца ў твор. Толькі вось чамусьці ТУТ $з$ крыжамі нагадвае ТАМ.

Чытаючы падобныя вершы 3 нестандартнымі формамі, увесь час задумваюся над тым, што імкнецца прадэманстраваць аўтар: што і са слоў можна канструяваць розныя геаметрычныя фігуры, што і слова - гэта будаўнічы матэрыял? У 1978 годзе Максім Танк пісаў у лісце да У. Калесніка пра А. Разанава: «...хоць на лішнюю усскладнёнасиь паэту варта было б звярнуцьь большую ўвагу, бо ўсе тэктанічныя награмаджэнні $і$ зрухі толькі тады маюць ращью, калі новыя тэматычныя пласты нельга уускрыць больш простым спосабам». Гісторыя форматворчасці павінна заклікаць да асэнсаванага эксперыментатарства, якое, гаворачы словамі Максіма Танка, уздымае «новыя тэматычныя пласты» на паверхню мастаикай свядомасиі. Многія сучасныя паэты не маюиь здольнасиі актуалізаващь літаратурныя традыщьы дзеля тлумачэння ўласных пошукаў. I калі гаварыць пра сучасную інтэлектуальную паэзію, то «працягнутасиь у будучыню не менш характэрна для свядомасиі, чым прадаўжэнне ў мінулае» [Хёсле 1994: 115], і не менш важна для ўспрымання і ацэнкі твора. Гісторыя вершатворчасці захоўвае цікавыя факты ўздзеяння формы на змест твора, і тут варта звярнуцца да рускай класічнай паэзіі. Сёння не выклікае сумненняу сцверджанне, што форма i эксперыменты 3 формай 
верша набылі ролю фармальнай ідэнтычнасці, здольнай прадвызначаць рэальную ідэнтычнасць мастацкага твора.

I тут варта ўзняць яшчэ адно пытанне: наколькі форма верша можа стаць выразнікам «жаночага стылю» у паэзіі. Звернемся да верша Т. Барысюк «Плынь свядомасці»:

Каханне.

Фобія.

Манія.

Вар'яцтва.

Блуканне.

Люстэркаў галерэя.

Надзея

без надзеі - я.

Сама ў сабе, як сэнс у форме.

У норме

і не ў норме.

Шукаю.

Філасофствую.

Баюся,

што некалі

ў люстэрку

не 3'яўлюся [Барысюк 2002: 107-108].

У пералічэннях зафіксаваны станы гераіні як ментальныя станы. Яна рухаецца ад мінулага да будучыні праз асэнсаванне душэўных ваганняў, сардэчных перажыванняў, блуканняў думкі... На гэтай рэфлексіўнай здольнасці асобы ўслухоўвацца ў сябе і фіксаваць зменлівыя станы ўнутранага свету пабудаваны верш Т. Барысюк. Каханне выклікае ў арганізме «хімічную рэакцыю», якая спараджае «фобію», «манію», «вар'яцтва» і «блуканне». У падобнай паслядоўнасці «пабочных» эффектаў кахання бачыцца 
своеасаблівая дыялектыка пачуцця гераіні, якая і дазваляе нам гаварыць пра «жаночае» акрэсліванне ўласнай самасці. Прынцыпам індывідуацыі ў творы выступае раздвоеная асоба - «у норме і не ў норме». Увогуле «я» сучаснага аўтара навучылася назіраць за сваёй самасцю і пачуццямі, быццам тыя ў многім адрозныя ад праяўленняў гэтага «я» і 3 ім не атаясамліваюцца. Праблема ідэнтыфікацыі «я» і самасці гэтага «я» ў мастацкім творы вельмі ўмоўная і нядоказная, таму што ў любым выпадку выходзіць на атаясамліванне «я» аўтара і «я» лірычнага героя. А за гэтай звязкай - шмат праекцый, якія цяжка ўкласці ў адназначныя схемы. Развагі паэтэсы агучваюць нашу тэорыю: рух яе думак з'яўляецца ўвасабленнем універсальных, нарматыўных і індывідуальных спосабаў прэзентацыі самасці асобы. «Каханне» - з'ява ўніверсальная, яго спазнае ў жыцці вялікая колькасць людзей, а вось пражыванне кахання - з'ява індывідуальная, як вынікае з верша Т.Барысюк - $з$ рознымі наступствамі. А заява лірычнай гераіні - «сама ў сабе, як сэнс у форме» - падкрэслівае ўнікальнасць яе самасці, непадобнасць на іншых. Яна не адчувае крызісу ідэнтычнасці, яна імкнецца адлюстраваць фарміраванне ўласнай ідэнтычнасці праз пераадоленне крызісаў.

Такім чынам, форма верша працуе на ідэю: у тэксце Барысюк радкі ўяўляюць з сябе асобнае слова, а за ім цэлая гісторыя, таму кропкі аддзяляюць нават не словы, а гісторыі ў лёсе гераіні. Быццам знаёмы і распаўсюджаны спосаб афармлення думкі - літаратурны штамп, аднак у кожным творы ён працуе на раскрыццё самасці аўтара і яго літаратурнага героя. Як, напрыклад, у вершы Аляксея Арцёмава «Развітанне»:

Апошні позірк вокамгненны,
Вакзал, цягнік, узмах рукой,
Крывёй напоўненыя вены,
Твой пульс і страчаны спакой... [Арцёмаў 2010: 10] 
I у T. Барысюк, і ў А. Арцёмава ў аснове кампазіцыі верша пералік падзей, станаў. Аднак у Барысюк яны падаюцца за кошт вынясення іх у асобны радок як розных, паслядоўных і хаатычных, эпізодаў жыцця, у Арцёмава за кошт таго, што яны аддзяляюцца коскамі і ўваходзяць у якасці аднародных членаў у адзін сказ, успрымаюцца складнікамі аднаго моманта, эмацыйнага і вельмі напружанага. Безумоўна, нельга параўноўваць без агаворак названыя творы, таму што яны розныя па ідэйна-тэматычным напаўненні, аднак дадзенае параўнанне дае нам магчымасць убачыць, як форма тэкста, размеркаванне ў ім сінтаксічных адзінак можа пашырыць ці звузіць змест твора, надаць яму рух, ці звесці ўсе намаганні аўтара да статычнага апісання. Арцёмаву дастаткова было чатырохрадкоўя, каб данесці да чытача трагедыю развітання закаханых. Такім чынам, форма можа ўпарадкаваць рух думкі, надаваць ёй паступовую, без хістанняў і без адыходу ад тэмы, дынаміку. Калі аўтар выбірае форму абдумана і загадзя, ён імкнецца запоўніць прастору абранай формы самымі трапнымі і дакладнымі словамі, у якіх сканцэнтравана паўставалі б у адзінстве ідэя і аўтарскі стыль. У іншых выпадках менавіта думка ці эмацыйны стан аўтара кіруе афармленнем тэкста ў пэўнай форме ці нават патрабуе нестандартных падыходаў, напрыклад у вершы Уладзіміра Скарынкіна «Багаслаўляю і люблю»:

Багаслаўляю і люблю

Я тое рэдкае імгненне,

Калі сыходзіць на зямлю

I на душу супакаенне,

Калі адолена бяда

І зноукку я аб шчасці мрою,

Калі былога не шкада -

Відаць, таму,

Што ты са мною.

Са светлым смуткам і тугой 
Калі блакітнаю смугой

Лугі засцелюцца ля гаю,

Калі аціхнуць чараты

І пад развесістай вярбою

Нягучна заспяваеш ты -

Відаць, таму,

Што я $з$ табою [Скарынкін 2005: 187].

Першая страфа ўяўляе $з$ сябе 9 радкоў, затым асобны радок без знаку прыпынку на канцы, наступная страфа складаецца 3 7 радкоў. Здавалася б, алагічная форма твора, аднак і за такой знешняй адсутнасцю логікі глыбінны сэнс: у першай страфе аўтар спявае хвалебную оду ці нават гімн любімаму чалавеку, словы зліваюцца ў трапяткое прызнанне i, здаецца, спыніцца немагчыма. I тут прысутнічае літаратурны канон - мы даведваемся пра адрасатааб'екта прызнання толькі ў канцы страфы. Але... у радасны настрой прасяквае «светлы смутак і туга». Радок «са светлым смуткам і тугой» - мае дачыненне як да аб'екта звароту, так і да самога лірычнага героя, ад імя якога будуецца маналог; ён разбівае тэкст на дзве самастойныя па часе і псіхаэмацыянальным настроі часткі. У першай частцы - канстатацыя спазнанага душой лірычнага героя «рэдкага імгнення», у другой частцы - жаданне далучыць да гэтага спазнання і каханага чалавека. «Светлы смутак і туга» падсвечвае лірычную настроенасць закаханага героя, надаючы ёй меладраматычную танальнасць. Зыходзячы $з$ падобнай канструкцыі верша, можна сцвярджаць, што гэта разбіўка апраўдана дынамікай эмоцыі і пачуцця ад узнеслага да лірычнага стану.

Такім чынам, форма не набывае пэўна акрэсленых рыс феміннасці/маскуліннасці ў паэтычным тэксце, аднак, калі б правесці статыстычны аналіз, упэўнена, што выявіліся прыхільнасці жанчын-аўтараў і мужчын-аўтараў да тых або іншых форм тэксту. Эксперыментуюць паэты са словам і яго афармленнем у творы незалежна ад полавай прыналежнасці. 
Аднак, у рускай і беларускай мове базавай ці першапачатковай з'яўляецца менавіта мужчынская слоўнікава-граматычная форма. Дамінанта мужчынскай формы слова над жаночай заўважана і асуджана феміністскай крытыкай. I калі феміністкі ваявалі 3 фешытызацыяй «фалічнай культуры», то сёння ўсё часцей крытыка скіроўвае свой гнеў на безаблічнасць мастацкага твора. Увогуле свет паэзіі рухаецца да ўніверсальнасці, нівеліроўкі, аднастайнасці у мужчынскіх і жаночых формах і спосабах апісання сябе і свету. I не па той прычыне, што жанчыне надакучыла быць жанчынай, а мужчыне мужчынам. Усё меней застаецца недатыкальных літаратурных канонаў, традыцыйных клішэ і ўстаялых шаблонаў у паэтыцы. Сучасным аўтаркам становіцца цесна ў жаночай граматыцы, яны імкнуцца пашырыць поле прыкладання паэтычнамоўнай думкі. Усё часцей сустракаюцца вершы, у якіх жанчынааўтар гаворыць ад імя мужчыны, напрыклад у вершы «***Што жыццё...» В. Куставай:

Што жыццё?.. -

Без пачатку і скону...

Мною зроблены просты выбар:

Да цябе,

А не да іконаў

Я ўзляцеў - і праз тое выбыў!..-

Па-за межы наіўнае мроі!.. [Кустава 2006: 17]

Абыгрываюцца ролі агульнавядомых літаратурных герояў (у дадзеным выпадку - Фаўста Ё. В. Гётэ), гістарычных дзеячоў, сусветнавядомых асоб і г. д. Таксама злучаецца мужчынскі і жаночы род, выкарыстоўваецца мужчынскі род замест жаночага ці ўвогуле абыходзяцца гендэрна-граматычныя маркіроўкі. Падобная змена масак дазваляе аўтару выходзіць за межы агульнапрынятых літаратурных шаблонаў і экстрапаліраваць на забароненыя некалі для жанчыны сферы мужчынскага. Але і ў такім дазволе- 
ным спосабе самараскрыцця сучасная аўтарка-жанчына адчувае адсутнасць свабоды - яна ці запазычвае ўжо гатовыя формулы стварэння мастацкага тэкста, ці іх імітуе, што прымушае яе шукаць новыя спосабы самапрэзентацыі, індывідуалізаваныя і непаўторныя. I ўсё часцей на старонках перыядычных выданняў сустракаем артыкулы, у якіх узнімаецца пытанне: ці існуе жаночае пісьмо і жаночы стыль пісьма, якія б сталі адкрыццём паэтэсы новага пакалення, вызваленай ад уціску маскуліннай традыцыі ў літаратуры?

«С. Вайгель лічыщь, ито жаночы стыль пісьма - небяспечнае панящие і крытыкуе яго па дзвюх прычынах. Таму што, папершае, жаночкі стыль звычайна вызначаюць фармальнымі рысамі, лічаць, напрыклад, што для яго з'яўляющйа тыповымі разрыўнасщьь, адступленні, непаслядоўнасиь, суб'ектыўнасиьь $i$ г. д. Гэтыл рысы даследчыцы-феміністкі лічащуь станоўчымі $i$, адпаведна, іншыя рысы (лагічнасиь, рэгулярнасиь, аб'ектыуунасиь) адмоўнымі, г.зн. стварающйа жорсткія вызначэнні "жаночага стылю" і мяркуещца, ито гэтыя рысы ўніверсальныл. Па-другое, такое паняцие стварае дуалізм паміж маскулінным і фемінным, а такі дуалізм заўсёды ставіцьь жанчьну ў горшае становішча $\check{y}$ параўнанні з мужчынам» [Рюткёнен 2012]. Сапраўды, і ў «обыденном» разуменні доўгі час лічылася, што жаночыя вершы адрознівае большая мяккасць і лірычнасць (нават сентыментальнасць), а мужчынскія - большая цвёрдасць і жорсткасць. Аднак шматлікія паэтычныя зборнікі, якія 3'явіліся уу апошнія дзесяцігоддзі, сцвярджаюць адваротнае: усе пералічаныя якасці не з'яўляюцца прывілеяй канкрэтнай гендэрнай групы, сёння жаноцкі мужчынскі і мужчынскі жаночы стылі - 3'ява даволі распаўсюджаная і ў прозе, і ў паэзіі. Так, чытаючы верш Анатоля Шушко «Каханне», немагчыма не адчуць, колькі мяккасці, цяпла, святла, пяшчоты ўкладзена ў кожнае слова, - тых эмацыянальных якасцей, якія быццам бы характэрны жаночаму стылю: 
Гэтулькі ўва мне святла, Любая,

Што забыў, як ты была

Згубаю.

Гэтулькі ўва мне вясны -

Крэўнасці, -

Што забыў пра гора-сны

Рэўнасці.

Гэтулькі ўва мне цяпла

Роднага,

Што забыў, як ты знайшла

Роўнага.

Рознае у нас было,

Ветлая,

Каб аднойчы, ды знайшло -

Светлае [Шушко 2011: 46].

Вынесеныя ў асобныя радкі словы бяруць на сябе ролю энергетычных носьбітаў твора - яны надаюць выказванням асаблівую мілагучную танальнасць, расстаўляюць лагічныя акцэнты, вызначаюць яго «сексуальны» падтэкст. Не трэба тлумачыць, што сексуальнасць верша звязваецца $з$ характарам, тыпам, узроўнем разняволенасці мовы верша - i адпаведна, самога аўтара. У гісторыі літаратуразнаўства сексуальнасць атаясамлівалася 3 цялеснасцю, атрыбутамі вонкавай прыгажосці асобы, адлюстраванымі ў тэксце. Варта дадаць, што сексуальнасць твора ў многім залежыць і ад эмацыйных канатацый, укладзеных у кожнае слова паэтычнага прызнання. А ў дадзеным творы - сексуальнасць не вычурная, не крыклівая, а спакойная, чыстая, збалелая. Пры прачытанні сэрца тахкае ва ўнісон з разбіўкай радкоў. У вершы Шушко з мужчынскім пачаткам звязана ідэя развіцця і руху думкі у некалькіх радках аўтар змог зафіксаваць гісторыю кахання і расстання, $з$ жаночым пачаткам - асаблівая мяккая танальнасць, зва- 
рот да фальклорных форм як да сродку апісання душэўнай траўмы і пакут разбітага сэрца. Для лірычнага героя і пасля расстання Яна засталася ўвасабленнем ідэальнай жаноцкасці - «любая» і «ветлая», таго святога месца, куды імкне памяць у пошуках прыстанішча. «Сексуальнасць» мужчынскага лірычнага прызнання становіцца выяўленнем андрагіннай прыроды чалавека, якая ў кожным 3 нас, аднак далёка не кожны ўмее ўраўнаважыць у сабе гэтыя два дыхатамічныя полюсы і дазволіць гэтаму «выдрэсіраванаму зверу» кіраваць мастацкай свядомасцю. «Андрагінны тып» мастацкага мыслення аўтара ўсё болей раскрываецца ў празаічных творах, аднак не ў навіну гэта і ў паэзіi.

Увогуле рамантычныя дыхатоміі неба/зямлі, святога/прафаннага, духоўнага/цялеснага маюць вялікую ролю ў самаапісанні і самаідэнтыфікацыі сучасных аўтараў. Праз іх яны не толькі акрэсліваюць межы засваення асобай прасторы сучаснага свету, але і прасторы магчымага/немагчымага ў літаратурным дыскурсе. Напрыклад, верш «***Калі жанчына разьнімае ногі...» Леры Сом пабудаваны на складаным сілагізме, пасылкі якога ўзыходзяць да супрацьдзеяння літаратурнаму канону - паэтэса не мае права гаварыць пра прыватнае, асабістае ў адкрытай і даверлівай форме без таго, каб не трапіць пад вызначэнне жанчыны лёгкіх паводзін. Тут сутыкаюцца ўніверсальны нарматыўны падыход да межаў дазволенага ў паэтычным тэксце, i ў прыватнасці - у жаночым тэксце, і індывідуальная апісальная трактоўка вобразу гераіні, якая займаецца самааналізам падчас сексуальнага акта:

Што думае яна у гэты момант?..

«Нішто памеры», «Прыкупіць бы бульбы», «Надвор'е - клас, я файна загарэла», «Наступны раз не забываць пракладку», 
«Я сыну

не сказала пра капусту»,

«Хачу на мора»,

«Хоць бы заплацілі»...

Ці думае яна:

«Ах, ён кахае, мяне кахае, я яго хачу,

хадзі хутчэй, хутчэй хадзі сюды...».

Я думала пра ўсё гэта з усімі.

Я ні пра што ня думаю з табой [Сом 2007: 70].

Першая частка як увасабленне рэальнай (індывідуальнай) ідэнтычнасці верша, што прапагандуе адсутнасць усякіх норм і стандартаў у раскрыцці пачуццяў; другая частка (са слоў: «Ці думае яна...») - фармальная ідэнтычнасць, што сілкуецца класічнымі формамі ў адлюстраванні палкасці і таму ўяўляе з сябе літаратурны шаблон. Фінальнае двухрадкоўе як перакрэсліванне гэтых дзвюх стыхій, што спаборнічалі паміж сабой за права быць прапаведнікамі ісціны ў мастацкім адлюстраванні асобы і яе перажыванняў. Інтэртэкстуальнасць прысутнічае на ўсіх узроўнях кампазіцыі верша, умоўна падзяляючы яго на некалькі частак. Верш «пра каханьне» Леры Сом не ўкладваецца ў статычныя формы, якія характэрны любоўнай лірыцы і якія належаць да так званай «калектыўнай ідэнтычнасці» падобнага кшталту твораў. Усё часцей аўтары свядома пазбягаюць нарматыўных вобразаў тэксту, заведама карыстаюцца антынарматыўным наборам прыёмаў дзеля разбурэння застаялых уяўленняў пра дазволенае/недазволенае ў літаратуры. Аднак падобныя свабоды ў аўтарскай самапрэзентацыі не заўсёды добра працуюць на змест твора, яго ідэйна-тэматычную скіраванасць і г.д. Калі звярнуцца да вершаў А. Шушко і Л. Сом, то, на мой погляд, «сексуальнасцю» валодае менавіта верш Шушко - ён кранае душу, перажыванні чытача значна больш, чым рэфлексіі ў пасцелі гераіні Леры Сом, якія скіраваны больш на думку і эстэтычнае ўспрыняцце чытача. У тэксце Сом больш мас- 
куліннага - мужчынскай жаноцкасці, чым у Шушко. Андрагінная сутнасць паэтэсы выявілася ў характары стварэння верша і надала яму пэўную адстароненасць ад узораў класічнай любоўнай лірыкі. Тут вельмі дарэчы будзе вызначэнне Э. Сіксу жаночай несвядомасці, якая часта i кіруе словам, што яна, «у адрозненне ад мужчынскай несвядомасці - у працээе пісьма пагльнаещчца імкненнем пачащь, прыступіць з усіх бакоў адразу, абазначыць некалькі заходаў адначасова, не засяроджваючыся на адным фалічным парыванні пачаць і скончыщь. Жаночае ияллеснае пісьмо можа мець

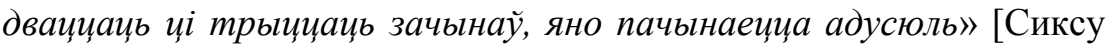
1995: 34-35].

Лера Сом $з$ дапамогай іроніі дэманструе ўціск «рознага» жаночага на «абсалютнае» жаночае, што павінна ўкладвацца ў межы дазволенага. Іронія як спосаб абароны ад выпрацаваных гісторыяй паэзіі схем у стварэнні мастацкага твора. Іронія і як спосаб візуалізацыі праз стыль падаўлення агульнапрынятых уяўленняў пра жаночае. Іронія таксама можа браць на сябе ролю шырмы ў тэатральным дзеянні твора. I калі мы ставім пытанне пра тое, якія спосабы і мадэлі пісьма жанчына і мужчына ўжываюць і чаму, немагчыма абысці ўвагай назіранне за жаночым і мужчынскім суб'ектамі як аўтарамі сваёй самасці і самасці лірычнага героя, што не абышліся без іроніі (звернемся да твораў Леры Сом і Анатоля Сербантовіча):

Каму з нас ведаць неахвота, Што грудзі ля вясковых хат Нальюцца хутка, быццам соты, У падрастаючых дзяўчат.

Дзяўчаты пойдуць карагодам,

Тады і зблізку і здаля

Здавацца будзе мне, што мёдам

Запахла ўся мая зямля [Сербантовіч 2007: 152]. 
У А. Сербантовіча іронія задзейнічана ў якасці скрытага механізма прачытання тэкста: чытач інтэрпрэтуе ў працэсе ідэнтыфікацыі тое, як 3 дапамогай мяккай іроніі мужчынскі суб'ект «упісваецца» ў тэкст, якія выклікае эмоцыі і г.д. Іронія выконвае ролю шырмы, за якой адбываецца яркае эратычнае дзеянне «грудзі ля вясковых хат» параўноўваюцца 3 налітымі грудзямі «падрастаючых дзяўчат». Быццам бы тут няма адкрытых эратычных вобразаў, як у Леры Сом - «сьцябла», які «знаходзіць кветку, пухнатую ці аголеную гладка» - аднак дадзенае параўнанне ў вершы Сербантовіча, не менш за асацыятыўныя вобразы Леры Сом, надае яму «сексуальную» афарбоўку. Лера Сом праз коды i канцэпты сусветнай паэзіі выводзіць чытача на сугестыўнае ўспрыняцце эратычных вобразаў, Анатоль Сербантовіч рухаецца далей: ад канкрэтызацыі да абсалютызацыі з'явы - наяўную і таемную сексуальнасць вылучае не толькі прыгожая маладая дзяўчына, яна ўсюды ў паветры. У вершы дамінуе ярка выражаная маскулінная самасць аўтара, суб'ект рэалізуе вынікі творчай працы ў формах, характэрных мужчынскай паэзіi, - па-перш, па прычыне таго, што жанчына не стане ўжываць у сваім пісьме падобнае параўнанне. А гэта значыць, што мастацкія тропы таксама набываюць гендэрную афарбоўку, а некаторыя нават і гендэрныя маркіроўкі «жаночага» і «мужчынскага» тропа.

Калі А. Шушко імкнецца ўкласці змест у стройную класічную форму і гэтым дасягнуць найбольшай гармоніi ў суадносінах літаратурнай нормы і аўтарскіх пошукаў, то ў Леры Сом адзначаецца сканцэнтраванасць на прыватным моманце, фрагментарнасць і эпізоднасць і адсутнасць строгай кампазіцыі. А. Сербантовіч увогуле рухаецца па ўзрастаючай: свае інтымныя перажыванні імкнецца перадаць свету, нагадаць, што ў прыватным (налітых грудзях падрастаючых дзяўчат) тоіцца велізарная эратычная энергетыка, здольная ахапіць усю зямлю. Дзве страфы верша «*** Каму 3 нас ведаць неахвотна» напоўнены цялеснай атрыбутыкай, якая працуе на «сексуалізацыю» мастацкага слова. Сербантовіч яўна 
прэзентуе аўтарскі мужчынскі пачатак, Шушко карыстаецца «феміннымі» стылістычнымі сродкамі, а Лера Сом, наадварот, пазбягае яўнай жаночай ініцыятывы (нягледзячы на наяўнасць у тэксце набору чыста жаночых прадметаў, кшталту «забытых жаночых пракладак», ці важнай у сферы псіхалогіі пола тэмы «нішто памеры», якая якраз і актуалізуецца жанчынай), таму што сама падача ідэі твора нагадвае агрэсіўнае адстойванне ўласнай думкі на «цялесныя адносіны» мужчыны і жанчыны, а гэта ўжо перанятая ў мужчын прывілея. Дамінанта андрагіннага пачатку ў самасці паэтэсы якраз і прадвызначае прысутнасць у тэксце маскулінных інтэнцый.

Такім чынам - перад намі тры спосабы перадачы любоўнага перажывання і тры розныя мадэлі верша пра каханне. Як вынікае 3 аналізу твораў, аўтары - суб'екты паэтычнага дыскурсу - выкарыстоўваюць у розных прапорцыях складнікі «фармальнай» і «рэальнай» ідэнтычнасці твора ў раскрыцці інтымных пачуццяў. А гэта ў вініку ўздзейнічае на пераразмеркаванне суб'ектна-аб'ектных адносін у тэксце i, адпаведна, на рэалізацыю ідэі верша.

\section{БІБЛІЯГРАФІЯ}

Гронская 2011: 76 - Гронская В. Гуляючы ў неверагоднасць: падборка вершаў / Маладосць. -2011 . - № 8 .

[Хёсле 1994: 112], [Хёсле 1994: 115] - Хёсле В. Кризис индивидуальной и

коллективной идентичности // Вопросы философии. - 1994. - № 10.

Барысюк 2002 - Барысюк Т. Аўтапартрэт: Вершы. - Мінск, 2002.

Арцёмаў 2010 - Арцёмаў А. Вершы / Беларус. - Нью-Ёрк. 2010. - С. 10.

Скарынкін 2005 - Скарынкін У. «Багаслаўляю і люблю» / Дзень паэзіі-2005. -

Мінск, Маст.літ., 2005.

Кустава 2006 - Кустава В. Тамсама: Вершы. - Мінск, Маст.літ., 2006.

Рюткёнен 2012 - Рюткёнен М. Гендер и литература: проблема «женского письма»

и «женского чтения» // [Рэсурсы Інтэрнета]: http://www.a-z.ru/women_cd1/html

/filologich_nauki_2.htm

Шушко 2011 - Шушко А. Камяні: падборка вершаў / Маладосць. - 2011. - № 8.

Сом 2007 - Сом Л. Каралева прыйдзе ноччу: Вершы пра каханьне. - Мінск,

Выдавец І. П. Логвінаў, - 2007.

Сиксу 1995 - Сиксу Э. La sexe ou la tete? (Женщина - тело - текст) //

Художественный журнал. -1995 . - № 6.

Сербантовіч 2007 - Сербантовіч А. Вершы / «Адсюль выток, адсюль натхненне...»: Паэзія, проза, публіцыстыка. - Мінск, Маст.літ., 2007. 